\section{World Bank's hint of green}

\section{Washington}

A $\$ 20$ million World Bank forestry loan to Sri Lanka, approved on 15 June, is being welcomed by environmentalists as an indication that the Bank is finally taking environmental issues seriously.

Pressure from local and international environmental groups resulted in lastminute renegotiation of the terms of the loan to incorporate stringent environmental safeguards, including suspension of logging in natural forest areas until environmental impact assessments are carried out.

But despite a commitment to giving environmental issues higher priority, announced in a 1987 speech by World Bank president Barber Conable, critics say little has changed. There is now an environment department and four regional units, but the new department is said to have too few technical experts and to have little influence over powerful regional directors.

The Environmental Defense Fund (EDF), long a stern critic of the Bank's environmental record, is due to give evidence before the Senate on $10 \mathrm{July}$, and although some positive changes will be reported, its criticisms will be modified only slightly from those of previous years.

In evidence to the House subcommittee on foreign operations, Bruce Rich, a senior attorney with the EDF, said that "for every case where there appear to be promising changes we can identify two or three ecological and social debacles of equal or greater scale where the Bank refuses to act even when apprised of the facts".

The director of the Natural Resources EUROPEAN COMMISSION

\section{Call for European version of EPA}

\section{Paris}

THE success of ecology parties in last week's European Parliament elections has given new life to European Community (EC) proposals to set up an agency to monitor pollution. A revived initiative was announced in Brussels last week by the EC Environment Commissioner, Mr Carlo Ripa di Meana. The aim of the agency would be to gather comparable data from the twelve member states on air, water and soil pollution. Britain has voiced reservations on the grounds that such an agency could interfere with existing national organizations, but some EC members do not have extensive monitoring structures and, at present, measures taken by other states sometimes use differing criteria, making Europe-wide controls difficult.

Peter Coles
Defense Council, Thomas Stoel, said that the Bank's environmental impact assessment was unsystematic and did not meet "even the minimum accepted international standards". He also said the Bank should involve non-governmental organizations and the general public from donor and borrower countries in the design of projects, and he criticized its "strict secrecy".

Conable said last week that the Bank's new emphasis on environmental reform "had not been easy". Some developing countries resist environmental programmes because they are seen as being "foisted upon them" by industrialized countries. They perceive that "the advanced countries have found yet another excuse to impede the development of poor countries and to encroach upon national sovereignty in a modernday version of colonialism. He pointed out that more than 100 projects with significant environmental components will have been approved by the end of this year. Over the past two years almost $\$ 500$ million has been lent for projects that protect or develop forests, and that sum will be more than doubled in the next three years. He also said the Bank plans to lend $\$ 1,330$ million for environmental projects over the same period.

Jeremy Warford, an attorney in the Bank's environment department, says that environmental reform within the Bank has proceeded at a "tremendous pace". To criticize individual projects is misleading, he says, since the principal thrust of the Bank's environmental policy is to integrate environmental issues into loans to governments for macroeconomic change. By 1989 a comprehensive environmental report on each borrowing country will have been prepared and will be fed into the policy-making process.

The Senate foreign operations appropriations subcommittee, which has for more than six years kept up pressure on the Bank to introduce environmental reforms, won another victory last week when the treasury secretary Nicholas Brady agreed to include 'debt-for-nature' provisions into the so-called "Brady Plan" for the reduction of debt in developing countries. Under these provisions, a portion of a nation's foreign debt is purchased at a discount in exchange for a commitment by the debtor nation to environmental initiatives. Though the details of the plan are not yet clear, it is a significant change from the policies of previous administrations which have held that all of the debt should be repaid on market terms.

Christine McGourty

- The economic value of non-timber products of tropical forests is rarely taken into account - see the Commentary on page 655.
Queensland's space base threatened

\section{Sydney}

Plans for a commercial spaceport at Cape York, in the far north of Queensland, may disintegrate now that one of the two consortia formed to develop the proposal has dropped out of the running, claiming that demand for the facility will be insufficient to make the $\mathrm{A} \$ 350$ million project commercially feasible until the late 1990s.

A rival consortium, the Cape York Space Agency (CYSA), now intends to pursue the project, but concerns over international technology transfer issues, as well as pressure from environmental and aboriginal groups, also threaten the success of the proposed space base.

The first launch, planned by CYSA for late 1992, will use Soviet equipment, but this may prevent NATO member countries from using the spaceport because of regulations enacted by Cocom, the NATO Coordinating Committee on East-West trade policy, aimed at keeping US technology out of Soviet hands. Australian federal officials met their US counterparts in Washington last week, and are expected to meet again on 16 July, to clarify security controls and the extent of likely technology transfer resulting from use of the spaceport. With agreement between Australia and the United States, United Technologies, the US aerospace company, could be an equal joint partner with CYSA and the Japan Cape York Spaceport group.

But there are also problems on the home front. After the formal submission of plans by CYSA, expected in two months, the government will set guidelines for an environmental impact study. Objections are expected from environmental and aboriginal organizations.

Queensland's Minister for Industry and Technology, Rob Burbidge, has said that a special Cape York enterprise zone will be set up, allowing various tax advantages and freight and electricity concessions, but part of the site is on the Register of the National Estate, and is an area of national significance, according to Liz Bourne, coordinator of the Queensland Conservation Council.

Stephen Williams of CYSA says that neither trade nor environmental issues will force abandonment of the project. CYSA will rely on the federal government to solve the technology transfer problems, and will abide by any environmental restraints that are set by the Queensland government. "We still think it's a commercially viable project", says Williams. 